\title{
PENGARUH BOOK TAX DIFFERENCES DAN ALIRAN KAS OPERASI TERHADAP PERSISTENSI LABA
}

\author{
Azzahra Salsabiila S, Dudi Pratomo, Annisa Nurbaiti \\ Fakultas Ekonomi dan Bisnis, Universitas Telkom Bandung \\ Email:azzahras95@gmail.com
}

\begin{abstract}
Earning persistence is a component of Earning quality. This research aims to determine the effect of book tax differences and operating cash flow toward earning persistence. Book tax differences variable is projected with permanent difference and temporary difference variable because of the differences between accounting and fiscal policy. The population in this study are food and beverage sub sector manufacturer companies listed on Indonesia stock exchange during 2010 to 2014. The sample selection technique used is purposive sampling and 15 companies that are included within five-years period in order to get 75 samples were observed. The method of data analysis used in this research is panel data regression using the software Eviews 8.0. The results showed that the Permanent Differences, Temporary Differences and Operating Cash Flow have simultaneously significant effect on earning persistence. While partially Permanent Difference, Temporary Difference did not have any affect on Earning Persistences and Operating Cash Flow significantly affects the Earning Persistence in a positive direction. Based on the results, beside using Earnings, investors and other parties can use operating cash flows as an alternative to evaluate the performance of the company
\end{abstract}

Keywords: Book Tax Differences, Permanent Differences, Temporary Differences, Operating Cash Flows, Earning Persistences

\begin{abstract}
Abstrak: Persistensi laba merupakan salah satu komponen dari kualitas laba. Penelitian ini bertujuan untuk mengetahui pengaruh book tax differences dan aliran kas operasi terhadap persistensi laba. Variabel book tax differences diproyeksikan dengan variabel perbedaan permanen dan perbedaan temporer akibat dari perbedaan kebijakan akuntansi dan fiskal. Populasi dalam penelitian ini adalah perusahaan manufaktur sub sektor food and beverageyang terdaftar di BEI tahun 2010 sampai 2014. Teknik pemilihan sampel menggunakan purposive sampling dan diperoleh 15 perusahaan yang disertakan dengan kurun waktu 5 tahun sehingga didapat 75 sampel yang diobservasi. Metode analisis data dalam penelitian ini adalah regresi data panel dengan menggunakansoftware Eviews 8.0.Hasil penelitian menunjukan bahwa Perbedaan Permanen, Perbedaan Temporer dan Aliran Kas Operasisecara simultan berpengaruh signifikan terhadap Persistensi Laba. Sedangkan secara parsial Perbedaan Permanen, Perbedaan Temporer tidak berpengaruh terhadap Persistensi Laba danAliran Kas Operasiberpengaruh signifikan dengan arah positif terhadap Persistensi Laba. Berdasarkan hasil penelitian, maka untuk menilai kinerja perusahaan selain menggunakan laba, investor dan pihak lain dapat menggunakan aliran kas operasi sebagai alternatif lain yang menunjukkan performa perusahaan.
\end{abstract}

Kata Kunci: Book Tax Differences, Perbedaan Permanen, Perbedaan Temporer, Aliran Kas Operasi, Persistensi Laba 


\section{PENDAHULUAN}

Laporan keuangan merupakan salah satu sumber informasi tentang suatu entitas yang mencerminkan keadaan keuangan dari hasil operasi perusahaan dalam periode tertentu kepada pihak yang berkepentingan. Pengguna laporan keuangan biasanya dibagi menjadi dua, yaitu pihak internal perusahaan seperti manajer, karyawan, direktur. Sedangkan pihak eksternal perusahaan adalah pemegang saham, pemerintah, masyarakat, suatu organisasi dan lain lain.

Laporan keuangan terdiri dari neraca, laporan laba rugi, laporan perubahan ekuitas, dan laporan arus kas.Laporan keuangan juga berfungsi untuk menyediakan informasi yang menyangkut posisi keuangan, kinerja perusahaan, perubahan posisi keuangan yang akan digunakan untuk pengambilan keputusan. Salah satu penilaian kinerja perusahaan adalah dengan melihat laba. Laba dapat mencerminkan kondisi perusahaan, salah satu prediksi terhadap laba dapat dibentuk oleh informasi keuangan dan rasio keuangan yang terdapat dalam laporan keuangan. Hal ini sesuai dengan Pernyataan Standar Akuntansi (IAI, 2015) yang menyatakan bahwa informasi kinerja perusahaan, terutama profitabilitas, diperlukan untuk menilai perubahan potensial sumber daya ekonomi yang mungkin dikendalikan di masa depan.

Laba memegang peranan yang sangat penting bagi sebuah perusahaan. Dengan laba perusahaan dapat mempertahankan kelangsungan hidupnya dan melakukan berbagai pengembangan demi kemajuan usahanya. Laba yang berkualitas adalah laba yang mampu memprediksi laba dimasa yang akan datang (future earnings) (Penman dan Zhang,1999). Laba yang tinggi juga menjadi harapan bagi : (1) manajer dalam hal penentuan bonus yang akan diterima, (2) pemilik dalam hal perhitungan dividen, (3) karyawan dalam hal kompensasi yang diterimanya, (4) kreditur dalam memprediksi kemungkinan penerimaan bunga beserta pokok pinjaman yang diberikan, (5) pemerintah dalam hal penerimaan pajak (pajak penghasilan), dan lain-lain (Fajri, 2012).

Menurut Subramanyam dan Wild (2010:112) Dua proses utama dalam pengukuran laba adalah pengakuan pendapatan dan pengaitan beban. Karena untuk memperoleh laba dapat dihitung dengan total pendapatan dikurangi beban-beban. Laba yang persisten adalah laba yang mempunyai kemampuan sebagai indikator laba periode mendatang (future earnings) yang dihasilkan oleh perusahaan secara berulang-ulang (repetitive) dalam jangka panjang (sustainable)(Penman dan Zhang, 1999). Banyak penyebab terjadinya persistensi laba, baik dari eksternal maupun internal perusahaan. Salah satu isu yang berkembang adalah tentang perbedaan antara laba akuntansi dan laba pajak atau sering disebut laba fiskal (Book tax differences). Hal ini disebabkan karena adanya peraturan yang berbeda antara PSAK dan Undang- Undang perpajakan. Perbedaan ini disebabkan perbedaan tujuan dan kepentingan masing-masing diantara para pengguna informasi laba tersebut. Sebagai contoh laba yang tinggi tidak dikehendaki oleh manajemen karena akan menghasilkan penghitungan pajak yang tinggi, tetapi sebaliknya menjadi harapan bagi fiskus (pemerintah sebagai pemungut pajak), laba yang tinggi juga tidak dikehendaki oleh manajemen karena akan menimbulkan gejolak para karyawan jika tidak menaikkan kompensasi yang diterimanya. Terjadinya fenomena book tax ini menimbulkan peluang terjadinya manajemen laba dan kualitas laba perusahaan.

Penman (2001) menyatakan bahwa book tax defferences dapat digunakan sebagai diagnosa untuk mendeteksi adanya manipulasi biayautama suatu perusahaan. Selain itu Revsine et al. (2005) menyatakan bahwa sebuah kelebihan antara laba komersial dan laba 
fiskal ... merupakan sinyal bahaya potensial yang harus diselidiki, karena ... mungkin indikasi memburuknya kualitas laba, Palepu et al (2000) dalam Hanlon (2005) menyatakan bahwa semakin besar perbedaan antara laba akuntansi dan laba fiskal menunjukkan "red flag" bagi pengguna laporan keuangan. Perbedaan antara kedua kebijakan tersebut tidak mengharuskan sebuah perusahaan atau instansi untuk membuat dua laporan keuangan dalam satu periode, hanya saja harus membuat koreksi fiskal yang memuat hal - hal yang harus disesuaikan. Akibat dari adanya koreksi fiskal menyebabkan adanya perbedaan temporer (beda waktu) dan permanen (beda tetap) (Resmi, 2011: 403). Beda waktu adalah perbedaan yang bersifat sementara terjadi karena adanya ketidaksamaan saat pengakuan penghasilan dan beban oleh administrasi pajak dan masyarakat profesi akuntansi, sedangkan beda tetap adalah perbedaan yang terjadi karena peraturan perpajakan menghitung laba fiskal berbeda dengan perhitungan laba menurut standar akuntansi keuangan tanpa ada koreksi di kemudian hari(Gunadi, 2009: 311). Perbedaan inilah yang akan mempengaruhi laba suatu perusahaan dalam pelaporan pajaknya, apakah akan lebih besar atau sebaliknya.

Penelitian sebelumnya yang berkaitan dengan book tax differences dan persistensi laba adalah Persada (2010) yang menyatakan bahwa book tax gap permanen dan temporer secara signifikan berpengaruh terhadap persistensi laba. Selain itu Amelia (2013) menyatakan bahwa perbedaan permanen berpengaruh terhadap perubahan laba dan perbedaan temporer tidak berpengaruh terhadap perubahan laba, Pertiwi (2014) dalam penelitiannya mendapatkan hasil bahwa book tax differences temporer dan permanen menghasilkan persistensi laba yang rendah. Dewi (2015) menunjukan bahwa perbedaan temporer dan permanen berpengaruh positif terhadap persistensi laba.

Selain book tax differences beberapa literatur menyebutkan bahwa terdapat faktor lain yang mempengaruhi persistensi laba. Sloan (1996) menyatakan bahwa bukti komponen laba akrual menjadi kurang persisten menentukan laba dimasa yang akan datang dibandingkan dengan komponen aliran kas, karena discretionary akrual kurang persisten dibandingkan non-discretionary akrual. Selain itu Penman (2001) menyatakan bahwa persistensi laba juga ditentukan oleh komponen arus kas dan laba akrual yang terkandung laba saat ini, komponen akrual dari current earnings kurang persisten untuk menentukan laba masa depan.

Aliran kas merupakan suatu laporan keuangan yang berisikan pengaruh kas dari kegiatan operasi, kegiatan transaksi investasi dan kegiatan transaksi pembiayaan/pendanaan serta kenaikan atau penurunan bersih dalam kas suatu perusahaan selama satu periode. Aliran kas operasi adalah suatu proksi untuk melihat berapa kas yang dikeluarkan untuk menghasilkan laba dalam pengoperasiannya. Dalam penelitian sebelumnya banyak menggunakan aliran kas sebagai variabel moderating atau variabel kontrol yang mendukung penelitian. Pada penelitian ini penulis ingin mencoba menambahkan aliran kas operasi sebagai variabel independen seperti penelitian yang dilakukan oleh Chowijaya (2014).

Penelitian sebelumnya yang berkaitan dengan pengaruh aliran kas operasi terhadap persistensi laba adalah penelitian yang dilakukan oleh Amelia (2013) menyataan bahwa aliran kas operasi berpengaruh terhadap perubahan laba. Dewi (2015) menunjukan bahwa aliran kas operasi berpengaruh positif terhadap persistensi laba. Dan penelitian Chowijaya (2014) yang menyatakan bahwa arus kas operasi tidak memiliki pengaruh yang signifikan. 


\section{KAJIAN TEORI}

Kualitas Laba. Salah satu tujuan penyajian laporan keuangan yaitu bermanfaat dalam pengambilan keputusan ekonomi atau investasi, seharusnya laba yang disajikan merupakan laba yang berkualitas (Sutopo,2007). Laba yang berkualitas tinggi adalah laba yang mempunyai kemampuan tinggi dalam memprediksi laba di masa datang (Schipper dan Vincent, 2003).Kualitas laba menunjukkan tingkat kedekatan laba yang dilaporkan dengan hicksian income, yang merupakan laba ekonomik yaitu jumlah yang dapat dikonsumsi dalam satu perioda dengan menjaga kemampuan perusahaan pada awal dan akhir perioda tetap sama (Schipper dan Vincent, 2003). Suwardjono (2010) menyatakan hal yang sama terkait kualitas laba akuntansi ditunjukkan oleh kedekatan atau korelasi antara laba akuntansi dan laba ekonomik.Kualitas laba sering dikaitkan dengan perekayasaan laba (earnings management), karena laba yang telah mengalami perekayasaan akan menurunkankualitasnya. Pengertian perekayasaan laba sangat penting bagi pengguna laporankeuangan, termasuk akuntan karena dapat memperbaiki pemahaman tentang manfaatlaba, baik untuk pelaporan keuangan kepada investor, maupun dalam membuat suatukontrak (Scott, 2000).Namun, perekayasaan laba harus dapat dibedakan dengan salahsaji (misrepresentation) dan pendistorsian (distortion) karena perekayasaan labamenggunakan prinsip akuntansi yang dapat diterima (acceptable) untuk pelaporanhasil tertentu (Triyono, 2007).

Persistensi Laba. Persistensi laba merupakan laba yang mempunyai kemampuan sebagai indikator laba periode mendatang (future earnings) yang dihasilkan oleh perusahaan secara berulang-ulang (repetitive) dalam jangka panjang (sustainable). Sebaliknya, unusual earnings atau transitory earnings merupakan laba yang dihasilkan secara temporer dan tidak dapat dihasilkan secara berulang-ulang (non-repeating), sehingga tidak dapat digunakan sebagai indikator laba periode mendatang (Penman dan Zhang, 1999). Hanlon (2005) mengukur persistensi laba dengan menggunakan koefisien regresi $(\gamma 1)$ antara laba akuntansi sebelum pajak satu periode masa depan (PTBI $t+1$ ) dengan laba akuntansi sebelum pajak periode sekarang (PTBIt). Sedangkan Persada (2010) menghitung persistensi laba dengan perubahan laba sebelum pajak tahun berjalan yang terdiri dari laba sebelum pajak tahun ini dikurangi laba sebelum pajak tahun sebelumnya dibagi dengan total aset.Dalam penelitian ini penulis menggunakan rasio yang sama dengan Persada (2010) yaitu perubahan laba sebelum pajak tahun berjalan yang terdiri dari laba sebelum pajak tahun ini dikurangi laba sebelum pajak tahun sebelumnya dibagi dengan total asset.

$$
\text { PRST }=\frac{\text { Laba sebelum pajak } \mathrm{k}_{\mathrm{t}-1}-\text { Laba sebelum pajak }}{\text { Total Aset }}
$$

Book Tax Differences. Book tax differences adalah perbedaan besaranlaba akuntansi atau laba komersialdengan laba fiskal atau penghasilankena pajak.Poernomo (2008) menyatakan bahwalaba akuntansi adalah laba atau rugibersih selama satu periode sebelumdikurangi beban pajak yang dihitungberdasarkan prinsip akuntansi yangberlaku umum dan lebih ditujukanuntuk menilai kinerja ekonomi,sedangkan laba fiskal adalah laba atau rugi selama satu periode yang dihitung berdasarkan peraturan perpajakan dan lebih ditujukan untuk menjadi dasar penghitungan PPh. 
Akibat adanya perbedaan, maka setiap entitas diharuskan untuk membuat koreksi fiskal. Dengan adanya koreksi fiskal maka akan terjadi perbedaan yang diantaranya perbedaan tetap (permanent difference) dan perbedaan sementara (temporary differences). Dalam penelitian ini book tax differences diproyeksikan dengan perbedaan permanen dan perbedaan temporer.

Perbedaan Permanen. Perbedaan permanen adalah perbedaan yang terjadi karena peraturan perpajakan menghitung laba fiskal berbeda dengan perhitungan laba menurut standar akuntansi keuangan tanpa ada koreksi di kemudian hari. Perbedaan positif terjadi karena ada laba akuntansi yang tidak diakui oleh ketentuan perpajakan dan relief pajak, sedangkan perbedaan negatif terjadi karena adanya pengeluaran sebagai beban laba akuntansi yang tidak diakui oleh ketentuan fiskal (Suandy 2001).Perbedaan permanen terjadi karena administrasi pajak menghitung laba fiskal berbeda dengan laba pembukuan (menurut standar akuntansi) tanpa koreksi di kemudian hari (Gunadi, 2009: 311). Perbedaan permanen sebagai indikator book tax differences didapat dari laporan keuangan pada bagian rekonsiliasi fiskal dan dibagi dengan total aktiva (Persada, 2010).

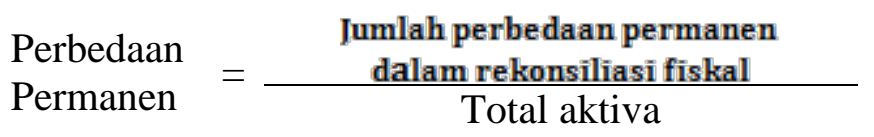

Perbedaan Temporer. Perbedaan waktu, yang bersifat sementara terjadi karena adanya ketidaksamaan saat pengakuan penghasilan dan beban oleh administrasi pajak dan masyarakat profesi akuntan (Gunadi, 2009: 311). Perbedaan temporer dapat dibagi menjadi perbedaan waktu positif dan perbedaan waktu negatif. Perbedaan waktu positif terjadi apabila pengakuan beban untuk akuntansi lebih lambat dari pengakuan beban untuk pajak atau pengakuan penghasilan untuk tujuan pajak lebih lambat dari pengakuan penghasilan untuk tujuan akuntansi. Perbedaan waktu negatif terjadi jika ketentuan perpajakan mengakui beban lebih lambat dari pengakuan beban akuntansi komersial atau akuntansi penghasilan mengakui penghasilan lebih lambat dari pengakuan penghasilan menurut ketentuan pajak. Untuk tujuan pelaporan keuangan, pendapatan diakui ketika diperoleh dan biaya diakui pada saat terjadinya (accrualbasic) (Suandy 2001). Persada (2010) menyatakan untuk menghitung perbedaan temporer didapat dalam laporan keuangan pada rekonsiliasi fiskal dan dibagi dengan total aktiva.

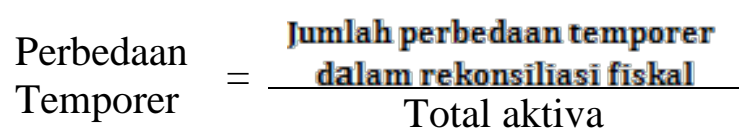

\begin{abstract}
Aliran Kas Operasi. Menurut PSAK No.2 (2015 :3) Arus kas adalah arus masuk dan arus keluar kas atau setara kas. Laporan arus kas berisi tentang ringkasan mengenai penerimaan dan pengeluaran kas suatu perusahaan dalam periode tertentu. Sedangkan aktivitas operasi menurut PSAK No.2 (2015: 3) adalah aktivitas penghasil utama pendapatan entitas (principal revenue-producing activities) dan aktivitas lain yang bukan merupakan aktivitas investasi dan aktivitas pendanaan. Dapat disimpulkan sesuai dengan definisi diatas bahwa aliran kas operasi atau arus kas operasi adalah arus masuk dan arus keluar kas atau setara kas yang berkaitan dengan penghasil utama pendapatan perusahaan atau suatu entitas.
\end{abstract}


Tujuan laporan arus kas menurut PSAK No 2 adalah memberikan informasi historis mengenai perubahan kas dan setara kas dari suatu perusahaan melalui laporan arus kas yang mengklasifikasikan arus kas berdasarkan aktivitas dari operasi, investasi, maupun pendanaan selama suatu periode akuntansi. Informasi arus kas memungkinkan para pemakai untuk mengevaluasi perubahan dalam aktiva bersih perusahaan, struktur keuangan (termasuk likuiditas dan solvabilitas), dan kemampuan untuk mempengaruhi jumlah serta waktu arus kas dalam rangka adaptasi dengan perubahan keadaan dan peluang. Informasi arus kas berguna untuk menilai kemampuan perusahaan dalam menghasilkan kas dan setara kas, dan memungkinkan para pemakai mengembangkan model untuk menilai dan membandingkan nilai sekarang dari arus kas masa depan (future cash flows) dari berbagai perusahaan.Saputro (2011) menyatakan bahwa besarnya jumlah arus kas operasi dapat dilihat pada laporan arus kas yang terdapat dalam laporan keuangan perusahaan dan diskala dengan total aktiva yang berada pada neraca.

$\begin{aligned} & \text { PreTax } \\ & \text { Cash Flow }\end{aligned}=\frac{\text { Jumlah arus kas operasi }}{\text { Total aktiva }}$

Aktiva. Aktiva atau aset merupakan sumber daya yang dikuasai oleh suatu perusahaan dengan tujuan menghasilkan laba (Subramanyam dan Wild,2008:271). Aset dapat digolongkan menjadi dua, yaitu aset tetap dan aset lancar. Menurut PSAK No.16 (IAI,2015) definisi aset tetap adalah aset berwujud yang dimiliki untuk digunakan dalam produksi atau penyediaan barang atau jasa untuk direntalkan kepada pihak lain, atau untuk tujuan administratif dan diharapkan untuk digunakan selama lebih dari satu periode. Sedangkan menurut Subramanyam dan Wild (2008:271) aset jangka panjang (long-lived assets), disebut juga aset tetap (fixed assets), atau aset tidak lancar (non-current assets) merupakan sumber daya atau klaim atas sumber daya yang diharapkan dapat memberikan manfaat pada perusahaan selama periode melebihi periode kini. Aset jangka panjang pada umumnya meliputi bangunan, peralatan, aset tak berwujud, investasi, dan beban- beban yang ditangguhkan.

Aset lancar (Current assets) merupakan sumber daya atau klaim atas sumber daya yang dapat langsung diubah menjadi kas sepanjang siklus operasi perusahaan (Subramanyam dan Wild,2008:271). Aset lancar diantaranya adalah kas, setara kas, efek, piutang, derivatif, persediaan dan beban diterima dimuka.Total aset atau aktiva adalah jumlah seluruh total aset tetap dan aset lancar, atau dalam persamaan akuntansi total aset dapat digambarkan dengan total liabilitas ditambah dengan total ekuitas (Reeve.et.al, 2009: 15)

\section{Total Aset = Total Liabilitas + Total Ekuitas}

Kerangka Pemikiran. Laba merupakan salah satu indikator dalam menilai kinerja suatu perusahaan. Kinerja perusahan yang baik tercemin pada laba yang berkualitas, Pengelompokkan konstruk kualitas laba dan pengukurannya menurut Schipper dan Vincent (2003) berdasarkan sifat runtun waktu dari laba, kualitas laba meliputi: persistensi, prediktabilitas (kemampuan prediksi) dan variabilitas.

Persistensi laba merupakan ukuran yang menjelaskan kemampuan perusahaan untuk mempertahankan jumlah laba yang diperoleh saat ini sampai satu perioda masa depan, atau persistensi laba merupakan laba yang mempunyai kemampuan sebagai indikator laba periode mendatang (future earnings) dan merupakan nilai prediktif yang tercermin dalam 
komponen akrual dan aliran kas. Selain itu labapun dipengaruhi oleh pajak yang dimana perhitungannya melibatkan laba kena pajak atau yang biasa disebut laba fiskal, besar kecilnya pajak kini ditentukan oleh jenis transaksi yang terjadi. Pengakuan transaksitransaksi tersebut ada yang diakui oleh fiskal dan tidak, sehingga menyebabkan perbedaan antara laba komersial dan laba fiskal (Book tax differences) yang tercermin pada perbedaan permanen dan perbedaan temporer

Perbedaan permanen terhadap persistensi laba. Perbedaan permanen pada bunga bank dalam SAK diperbolehkan sebagai penambah penghasilan tetapi dalam Ketentuan Peraturan Perundang-undangan Perpajakan tidak diperkenankan karena pajak yang dikenakan untuk bunga bank adalah pajak final yang akan dihitung dan dibayarkan sekaligus pada akhir periode pembukuan. Dalam rekonsiliasi fiskal yang dilakukan, hal ini merupakan koreksi negatif yang menyebabkan laba fiskal berkurang dan jumlah pajak terutang juga berkurang, sehingga apabila pajak yang dibayarkan perusahaan semakin sedikit sedangkan jumlah penghasilan sebelum pajak diasumsikan tetap maka laba bersih setelah pajak akan besar, atau dengan kata lain pertumbuhan laba juga akan meningkat. Hal ini menyebabkan hubungan yang positif pula terhadap persistensi laba. Sehingga, apabila perbedaan permanen bertambah maka perusahaan semakin persisten atau dapat meningkatkan laba.

Untuk itu disimpulkan sementara bahwa perbedaan permanen akan berpengaruh positif terhadap persistensi laba, atau perbedaan permanen menyebabkan laba perusahaan persisten dan dapat memprediksi laba pada tahun berikutnya, karena perbedaan permanen tidak menyebabkan perbedaan yang begitu besar. Hal ini sesuai dengan penelitian yang dilakukan oleh Persada (2010) dan Dewi (2015) yang menyatakan bahwa perbedaan permanen dalam book tax gap berpengaruh positif terhadap persistensi laba.

Perbedaan temporer terhadap persistensi laba. Apabila beban pajak tangguhan besar, maka jumlah beban pajak penghasilan terutang yang akan dibayarkan juga akan lebih besar karena beban pajak tangguhan ini akan menambah beban pajak kini yang akan menambah jumlah pajak pengahasilan semakin besar. Dengan asumsi penghasilan tetap dan jumlah pajak terutang yang dibayarkan besar, maka laba bersih (laba fiskal) akan semakin kecil dan pertumbuhan laba perusahaan akan menurun.

Untuk itu disimpulkan sementara bahwa perbedaan temporer akan berpengaruh negatif terhadap persistensi laba, atau perbedaan temporer menyebabkan laba perusahaan tidak persisten dan dapat memprediksi laba pada tahun berikutnya, karena perbedaan temporer menyebabkan penundaan pada pengakuannya. Hal ini sesuai dengan penelitian yang dilakukan oleh Persada (2010) dan Dewi (2015) yang menyatakan bahwa perbedaan temporer dalam book tax gap berpengaruh negatif terhadap persistensi laba.

Aliran kas operasi terhadap persistensi laba. Aliran kas operasi merupakan indikator utama untuk menentukan apakah operasi perusahaan dapat menghasilkan arus kas yang cukup untuk melunasi pinjaman, memelihara kemampuan operasi perusahaan, membayar dividen, dan melakukan investasi baru tanpa mengandalkan sumber pendanaan dari luar. Aliran kas operasi juga mencerminkan banyaknya kas yang dikeluarkan untuk beroperasi dengan kata lain memperoleh laba.

Apabila kas operasi berjumlah positif maka akan menyumbangkan laba dan begitu sebaliknya. Aliran kas operasi juga dianggap sebagai faktor utama dalam menetukan persistensi laba. Sehingga aliran kas operasi berpengaruh positif terhadap persistensi laba. 
Hal ini sesuai dengan penelitian Wijayanti (2006) Persistensi laba merupakan salah satu komponen nilai prediksi labaa dalam menentukan kualitas laba. Persistensi laba tersebut ditentukan oleh komponen akrual dalam aliran kas dari laba sekarang yang mewakili sifat transitori (sementara atau peralihan) dan permanen laba. Oleh karena itu aliran kas operasi berpengaruh positif terhadap persistensi laba sesuai dengan penelitian Dewi (2015).

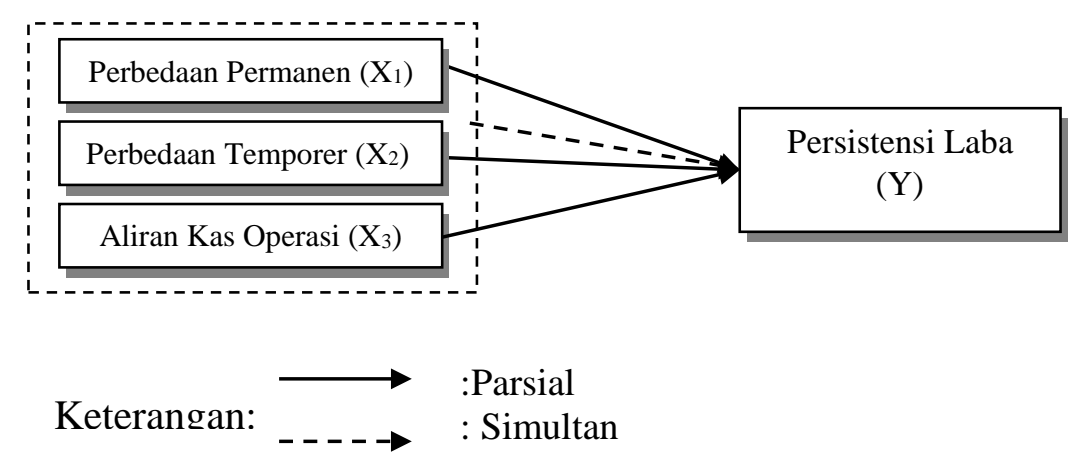

Gambar 1. Kerangka Pemikiran

Hipotesis Penelitian. Berdasarkan teori dan kerangka pemikiran yang telah dipaparkan pada sub bab sebelumnya, maka penelitian ini memiliki hipotesis sebagai berikut: (1) Book tax differences (perbedaan permanen dan perbedaan temporer) dan aliran kan operasi secara simultan berpengaruh terhadap persistensi laba pada perusahaan food and beverage yang listing di Bursa Efek Indonesia tahun 2010-2014Book tax differences (perbedaan permanen dan perbedaan temporer) dan aliran kan operasi secara simultan berpengaruh terhadap persistensi laba pada perusahaan food and beverage yang listing di Bursa Efek Indonesia tahun 2010-2014; (2) Perbedaan permanensecara parsial berpengaruh positif terhadap persistensi laba pada perusahaan food and beverage yang listing di Bursa Efek Indonesia tahun 2010- 2014; (3) Perbedaan temporersecara parsial berpengaruh negatif terhadap persistensi laba pada perusahaan food and beverage yang listing di Bursa Efek Indonesia tahun 2010- 2014; (4) Aliran kas operasi secara parsial berpengaruh positif terhadap persistensi labapada perusahaan food and beverage yang listing di Bursa Efek Indonesia tahun 2010-2014

\section{METODE}

Penelitian ini akan menggunakan sumber data sekunder berupa laporan keuangan tahunan perusahaan manufaktur subsektor food and beverage yang terdaftar di BEI tahun 2010-2014. Menurut Persada (2010) Perusahaan manufaktur dipilih karena karena memiliki karakteristik yang sama sehingga dampak BTG dapat lebih teramati, selain itu perusahaan lembaga keuangan memberikan hasil berbeda karena pendapatannya dipengaruhi oleh regulasi pemerintah, perusahaan konstruksi dikenakan pajak final dan pertambangan memiliki regulasi pajak yang berbeda. Populasi dalam penelitian ini adalah laporan keuangan perusahaan manufaktur subsektor food and beverage yang terdaftar di BEI tahun 2010-2014. Teknik sampel yang digunakan dalam penelitian ini adalah purposive sampling dengan kriteria diantaranya: (1) Perusahaan manufaktur di bidang food and baverage yang terdaftar di Bursa Efek Indonesia (BEI) pada tahun 2010- 2014 secara berturut- turut; (2) Mempublikasikan laporan keuangan yang telah di audit selama 
tahun penelitian; (3) Perusahaan tidak mengalami kerugian dalam laporan keuangan komersial dan laporan keuangan fiskal selama tahun pengamatan. Alasannya adalah kerugian dapat dikompensasi ke masa depan (carryforward) menjadi pengurang biaya pajak tangguhan dan diakui sebagai aset pajak tangguhan sehingga dapat mengaburkan arti book tax differences (Hanlon, 2005); (4) Memiliki kelengkapan informasi yang dibutuhkan terkait dengan indikator-indikator perhitungan yang dijadikan variabel pada penelitian ini.

Diperoleh 75 data observasi yang terdiri dari 15 perusahaan dengan periode penelitian selama 5 tahun.

Model Penelitian. Metode yang digunakan dalam penelitian ini adalah metode data panel (pooled regression). Data panel adalah data yang berstruktur urut waktu sekaligus cross section. Data panel diperoleh dengan mengamati serangkaian observasi cross section (antar individu) pada suatu periode tertentu(Ariefianto,2012:148). Alat analisis yang digunakan berupa software Eviews 8.0. Metode kuantitatif yang akan digunakan dalam penelitian ini adalah analisis ekonometrik kausal dinamis dengan mengaplikasikan metode kuadrat terkecil (least squares) pada model efek tetap (fixed effect) atau model efek acak (random effect). untuk menentukan model yang tepat dalam pengolahan data, kemudian dilakukan serangkaian pengujian statistik menggunakan uji Chow, uji Hausman dan juga uji LM (langrage multiplier). Persamaan untuk regresi data panel dapat dituliskan sebagai berikut:

$$
Y=\propto+\beta_{1} X_{1} \text { it }+\beta_{2} X_{2} \text { it }+\beta_{3} X_{3} \text { it } \varepsilon
$$

Keterangan: $\mathrm{Y}=$ Persistensi laba pada perusahaan i tahun ke-t; $\mathrm{X}_{1}$ it $=$ Perbedaan permanen pada perusahaan i tahun ke-t; $\mathrm{X}_{2} \mathrm{it}=$ Perbedaan temporer pada perusahaan $\mathrm{i}$ tahun ke-t; $X_{3}$ it $=$ Aliran kas operasipada perusahaan i tahun ke-t; $\propto \propto=$ Konstanta; $\beta_{1}, \beta_{2},=$ Koefisien regresi masing-masing variable; $\varepsilon=$ Error term .

\section{HASIL DAN PEMBAHASAN}

Analisis Statistik Deskriptif. Penelitian ini menggunakan laporan keuangan dengan sampel 15 perusahaan manufaktur subsektor food and beverage yang terdaftar di Bursa Efek Indonesia selama tahun 2010-2014. Adapun satuan waktu yang digunakan dalam penelitian ini adalah tahunan. Sehingga total data sebanyak 75 data yang digunakan sebagai sampel.Berdasarkan analisis statistik deskriptif berikut adalah hasil statistik deskriptif setiap variabel operasional. Tabel 1 menggambarkan statistik deskriptif variabel independen dan juga dependen.

Tabel 1. Hasil Pengujian Statistik Deskriptif

\begin{tabular}{ccccc}
\hline & BP & BT & AKO & PRST \\
\hline Mean & $-0,005100$ & -0.001420 & 0.131344 & 0.014919 \\
Max & 0.027700 & 0.069800 & 0.666300 & 0.544110 \\
Min & -0.132800 & -0.052900 & -0.243000 & -0.250940 \\
Std. Dev. & 0.024215 & 0.017423 & 0.138771 & 0.089024 \\
Obv & 75 & 75 & 75 & 75 \\
\hline
\end{tabular}

Sumber :Output eviews 8.0 dan Data diolah penulis (2016) 
Keterangan: $\mathrm{BP}=$ Perbedaan Permanen; $\mathrm{BT}=$ Perbedaan Temporer; $\mathrm{AKO}=$ Aliran Kas Operasi; PRST= Persistensi Laba

Dari data tersebut dapat dilihat bahwa variabel BP memiliki nilai rata- rata sebesar 0,005. Arti minus(-) dalam variabel ini menggambarkan bahwa adanya koreksi negatif yang dapat mengurangi laba kena pajak tahun berjalan dan menghasilkan pajak lebih kecil, sehingga laba yang dihasilkan akan semakin besar. Perusahaan yang memiliki perbedaan permanen diatas rata-rata selama tahun 2010-2014 sebanyak 55 observasi dan sisanya sebesar 20 observasi yang memiliki perbedaan permanen dibawah rata-rata. Nilai maksimum yang dimiliki variabel BP sebesar 0,0277 dan nilai minimum sebesar -0,1328. Selain itu nilai rata- rata sebesar -0,005 lebih kecil dibandingkan dengan standar deviasi sebesar 0,024 yang menunjukkan bahwa data pada variabel perbedaan permanen menyebar atau bervariasi. Hal ini disebabkan karena adanya beberapa perusahaan yang memiliki pengurang atau penambah baik dari sisi pendapatan maupun beban pada koreksi fiskalnya dengan jumlah yang berbeda- beda sesuai dengan transaksi yang terjadi setiap tahunnya baik rutin maupun tidak. Standar deviasi sebesar 0,024 dapat diartikan bahwa penyimpangan untuk variabel perbedaan permanen sebesar 0,024.

Nilai rata- rata yang dimiliki oleh variabel BT sebesar -0,001 atau adanya koreksi negatif yang dicerminkan oleh tanda minus(-) pada nilai rata- rata dan menghasilkan laba sebelum pajak lebih kecil. Sehingga pajak yang dihasilkan akan kecil.Perusahaan yang memiliki perbedaan temporer diatas rata-rata selama tahun 2010-2014 sebanyak 43 observasi dan sisanya sebesar 32 observasi yang memiliki perbedaan temporer dibawah rata-rata. Nilai maksimum yang dimiliki variabel BT sebesar 0,07 dan nilai minimum sebesar -0,053. Selain itu nilai rata- rata sebesar -0,001 lebih kecil dibandingkan dengan standar deviasi sebesar 0,017 yang menunjukkan bahwa data pada variabel perbedaan temporer menyebar atau bervariasi. Hal ini disebabkan karena adanya beberapa perusahaan yang memiliki item-item pengurang atau penambah pada laba kena pajak dengan jumlah yang berbeda- beda sesuai dengan transaksi yang terjadi setiap tahunnya baik rutin maupun tidak. Standar deviasi sebesar 0,017 dapat diartikan bahwa penyimpangan untuk variabel perbedaan permanen sebesar 0,017.

Nilai rata- rata yang diperoleh dari perhitungan statistik variabel aliran kas operasi adalah sebesar 0.131 yang berarti bahwa perusahaan cenderung memperoleh kas dari hasil operasinya. Hal ini dibuktikan dengan bilangan yang positif, sehingga pemasukan lebih besar dibandingkan dengan pengeluaran yang berarti perusahaan menggunakan kas nya dengan optimal untuk memperoleh kas kembali. Perusahaan yang memiliki aliran kas operasi diatas rata-rata selama tahun 2010-2014 sebanyak 34 observasi dan sisanya sebesar 41 observasi yang memiliki aliran kas operasi dibawah rata-rata. Selain itu nilai maksimum yang dimiliki variabel AKO sebesar 0,666 dan nilai minimum sebesar -0,243. Standar deviasi yang lebih besar daripada nilai rata- rata menunjukan bahwa data berkelompok atau tidak bervariasi. Standar deviasi sebesar 0,139 dapat diartikan bahwa penyimpangan untuk variabel aliran kas operasi sebesar 0,139.

Nilai rata- rata yang diperoleh dari perhitungan statistik variabel persistensi laba adalah sebesar 0.015 yang berarti bahwa tingkat persisten laba pada perusahaan food and beverage tahun 2010-2014 adalah sebesar 0,015. Perusahaan yang memiliki persistensi laba diatas rata-rata selama tahun 2010-2014 sebanyak 41 observasi dan sisanya sebesar 34 observasi yang memiliki perbedaan permanen dibawah rata-rata. Nilai maksimum yang dimiliki oleh variabel PRST adalah sebesar 0,544 dan nilai minimum sebesar -0,251. 
Standar deviasi pada variabel persistensi laba sebesar 0,089 yang lebih besar dibandingkan dengan nilai rata-rata sebesar 0,015 menyatakan bahwa data pada variabel persistensi laba tidak berkelompok atau bervariasi. Standar deviasi sebesar 0,089 dapat diartikan bahwa penyimpangan untuk variabel aliran kas operasi sebesar 0,089.

Secara keseluruh variabel operasional memiliki nilai mean yang lebih kecil dari standar deviasi yang dapat diartikan bahwa data variabel operasional tersebut tidak berkelompok atau bervariasi.

\section{Pemilihan Metode Estimasi Regresi Data Panel. Uji Fixed Effect (Uji Chow)}

Tabel 2.Hasil Uji Fixed Effect

\begin{tabular}{llll}
\hline Effects Test & Statistic & d.f. & Prob. \\
\hline Cross-section F & 0.641890 & $(14,57)$ & 0.8184 \\
Cross-section Chi-square & 10.979876 & 14 & 0.6876 \\
\hline
\end{tabular}

Sumber: Output Eviews 8.0 (data diolah penulis, 2016)

Berdasarkan hasil uji signifikansi fixed effect, diperoleh nilai probabilitas cross section Chi-square sebesar 0,6876 lebih besar dari taraf signifikansi 5\% dan nilai prob cross section $F$ sebesar 0,8184 lebih besar dari taraf signifikansi 5\%, maka $\mathrm{H}_{0}$ diterima atau penelitian ini menggunakan metode common effect. Selanjutnya dilakukan pengujian antara metode common effect dengan random effect menggunakan uji Lagrange Multiplier (LM).

\section{Uji Random Effect (Uji Lagrange Multiplier)}

Tabel 3. Hasil Uji Random Effect

\begin{tabular}{llll}
\hline $\begin{array}{l}\text { Null (no rand. effect) } \\
\text { Alternative }\end{array}$ & $\begin{array}{l}\text { Cross-section } \\
\text { One-sided }\end{array}$ & $\begin{array}{l}\text { Period } \\
\text { One-sided }\end{array}$ & Both \\
\hline \multirow{2}{*}{ Breusch-Pagan } & 3.770192 & 0.134150 & 3.904342 \\
& $(0.0522)$ & $(0.7142)$ & $(0.0482)$ \\
Honda & -1.941698 & 0.366265 & -1.113999 \\
& $(0.9739)$ & $(0.3571)$ & $(0.8674)$ \\
King-Wu & -1.941698 & 0.366265 & -0.592310 \\
& $(0.9739)$ & $(0.3571)$ & $(0.7232)$ \\
GHM & -- & - & 0.134150 \\
& -- & -- & $(0.5909)$ \\
\hline
\end{tabular}

Sumber: Output Eviews 8.0 (Data diolah penulis, 2016)

Berdasarkan hasil uji signifikansi random effect, diperoleh nilai probabilitas Breusch-Pagan (BP) sebesar 0,0522 lebih kecil dari taraf signifikansi 5\% menunjukkan 
bahwa nilai probabilitas ( $p$-value) $<0,05$ maka sesuai dengan ketentuan pengambilan keputusan bahwa $\mathrm{H}_{1}$ diterima atau penelitian ini menggunakan metode random effect.

Koefisien Detreminasi $\left.\mathbf{( R}^{2}\right)$. Berdasarkan analisis statistik deskriptif dapat diketahui bahwa perbedaan permanen dan temporer tahun 2010-2014 sudah baik yang ditunjukan dari banyaknya perusahaan yang berada diatas nilai rata-rata. Namun banyak perusahaan yang berada di bawah rata-rata pada variabel aliran kas operasi selama tahun 2010-2014 Hal ini disebabkan karena perusahaan sampel lebih banyak menggunakan kas nya dalam proses operasi.

Uji Signifikansi Simultan (Uji F). Berdasarkan hasil uji signifikasi simultan diperoleh bahwa nilai $F_{\text {hitung }}$ sebesar 4,930034 dan nilai $F_{\text {tabel }}$ sebesar 2.73, sehingga $F_{\text {hitung }}>F_{\text {tabel }}$ dan memiliki nilai probabilitas ( $p$-value) sebesar 0,003624 < 0,05 maka diketahui bahwa perbedaan permanen, perbedaan temporer dan aliran kas operasi memiliki pengaruh secara bersama-sama (simultan) terhadap persistensi laba. Variabel independen pada perusahaan sampel sebesar 13,7\% mampu menjelaskan variabel dependen yaitu persistensi laba, sedangkan sisanya 86,26\% dijelaskan oleh variabel lain diluar penelitian.

\section{Uji Signifikansi Parsial (Uji t)}

Tabel 4. Model Random Effect

\begin{tabular}{lllll}
\hline Variable & Coefficient & Std. Error & t-Statistic & Prob. \\
\hline C & & & & \\
BP & -0.019851 & 0.013450 & -1.475900 & 0.1444 \\
BT & -0.185547 & 0.406712 & -0.456214 & 0.6496 \\
AKO & 0.081045 & 0.561947 & 0.144223 & 0.8857 \\
\hline
\end{tabular}

Berdasarkan Tabel 4 dapat diketahui nilai konstanta koefisien sehingga dapat dibentuk persamaan sebagai berikut:

$$
\mathrm{PRST}=-0,019851-0,185547 \mathrm{BP}+0,081045 \mathrm{BT}+0,259615 \mathrm{AKO}+\varepsilon
$$

Berdasarkan hasil uji metode random effect model dapat disimpulkan bahwa:

Pengaruh perbedaan permanen terhadap persistensi laba. Berdasarkan hasil pengujian secara parsial dihasilkan variabel permanen memiliki nilai thitung sebesar -0.456214 dan $t_{\text {tabel }}$ sebesar 1.9939 sehingga $t_{\text {hitung }}<t_{\text {tabel }}$ dan hasil uji signifikansi yang dilakukan menunjukkan tingkat signifikansi sebesar 0,6496 yang lebih besar dari 0,05 dan $\mathrm{H}_{02}$ diterima yang artinya hasil pengujian menunjukkan variabel perbedaan permanen tidak memiliki pengaruh terhadap persistensi laba secara parsial, sehingga tinggi atau rendahnya perbedaan permanen tidak merubah variasi nilai persistensi laba pada perusahaan food and beverage yang terdaftar di BEI.

Koefisien regresi pada perbedaan permanen sebesar -0,185547 yang memiliki nilai negatif menunjukkan bahwa adanya hubungan yang berlawanan antara perbedaan 
permanen dengan persistensi laba, sehingga apabila perbedaan permanen semakin besar maka kemungkinan tingkat persistensi laba kecil dan begitu pula sebaliknya.

Hal tersebut disebabkan karena terdapat item-item perbedaan permanen seperti pendapatan yang dikenakan pajak final dan bukan objek pajak. Apabila terdapat pendapatan yang merupakan objek pajak final dan harus dikurangkan dari laba kena pajak maka akan menyebabkan laba kena pajak mengecil sehingga pajak yang harus dibayar juga kecil dan laba setelah pajak besar. Namun lain halnya apabila pengurangan tersebut diiringi dengan biaya yang bukan termasuk objek pajak yang harus ditambahkan pada laba kena pajak, sehingga laba sebelum pajak menjadi sama saja dan tidak terlihat perubahan yang signifikan.

Kerangka pemikiran yang dibangun oleh penulis pada awalnya hanya melihat pada satu sisi item perbedaan permanen saja yaitu pada pendapatan yang dikenakan pajak final. Perbedaan permanen memiliki dampak meningkatkan dan meurunkan laba kena pajak secara bersamaan sesuai dengan kondisi perusahaan tersebut. Pada pembahasan deskriptif diketahui bahwa 55 dari 75 observasi memiliki nilai rata-rata perbedaan permanen di atas rata-rata yang menyatakan bahwa sampel memiliki item-item yang merupakan objek pajak final dan bukan objek pajak. Nilai rata-rata sebesar -0,005 memiliki arti mengurangi laba kena pajak sebesar 0,5\% menunjukkan bahwa perusahaan sampel masih memiliki kegiatan yang bukan termasuk dalam operasi perusahaan.

Selain itu jumlah perbedaan permanen yang beragam pada setiap perusahaan sampel menyebabkan adanya variasi data yang dibuktikan dengan nilai rata-rata sebesar -0,005 lebih kecil dari standar deviasi sebesar 0,024. Angka tersebut mencerminkan adanya penyimpangan data sebesar 0,024.Besarnya jumlah perbedaan permanen yang tidak terlalu signifikan dengan jumlah laba sebelum pajak yang didapatkan oleh perusahaan, maka laba setelah pajak yang sebelumnya dikurangi oleh pajak kini yang terkandung perbedaan permanen tidak memiliki efek yang begitu menonjol dengan adanya perbedaan permanen

Hasil ini sejalan dengan penelitian yang dilakukan oleh Wihardiningrum dan Aryanti (2015) yang menyatakan bahwa BTG Permanen (PBTG) tidak memiliki hubungan signifikan terhadap persistensi laba. Namun, berbeda dengan penelitian terdahulu yang dilakukan oleh Persada (2010) yang menyatakan bahwa perbedaan permanen berpengaruh signifikan terhadap persistensi laba.

Pengaruh perbedaan temporer terhadap persistensi laba. Berdasarkan hasil pengujian secara parsial dihasilkan variabel perbedaan temporer memiliki nilai thitung sebesar 0.144223 dan tabel sebesar 1.9939 sehingga thitung $<t_{\text {tabel }}$ dan hasil uji signifikansi yang dilakukan menunjukkan tingkat signifikansi sebesar 0.8857yang lebih besar dari 0,05 dan $\mathrm{H}_{03}$ diterima yang artinya hasil pengujian menunjukkan variabel perbedaan temporer tidak memiliki pengaruh terhadap persistensi laba secara parsial, sehingga tinggi atau rendahnya perbedaan temporer tidak merubah variasi nilai persistensi laba pada perusahaan food and beverage yang terdaftar di BEI.

Koefisien regresi pada perbedaan temporer sebesar 0,081045 yang memiliki nilai positif menunjukkan bahwa adanya hubungan yang searah antara perbedaan temporer dengan persistensi laba, sehingga apabila perbedaan temporer semakin besar maka kemungkinan tingkat persistensi laba besar dan begitu pula sebaliknya. Hal ini terjadi karena pada perbedaan temporer terdapat item berupa aset pajak tangguhan, kewajiban pajak tangguhan, penghasilan pajak tangguhan dan beban pajak tangguhan yang akan mempengaruhi neraca dan laba rugi. Apabila ada koreksi positif akan menghasilkan 
penghasilan pajak tangguhan dan korensi negatif akan menghasilkan beban pajak tangguhan. Maka jika perbedaan temporer positif akan berdampak pada laba setelah pajak yang kecil saat ini dan besar dimasa depan. Sehingga sesuai dengan definisi persistensi laba yaitu laba yang persisten adalah laba yang mampu mempertahankan atau meningkatkan labanya dimasa yang akan datang. Pada hasil statistik deskriptif menunjukkan bahwa sebanyak 43 observasi berada di atas rata-rata dan 32 di bawah ratarata. Selisih dari kedua kategori tersebut sebanyak 9 data dengan rata-rata sebesar $-0,001$ yang memiliki arti perbedaan temporer mengurangi laba kena pajak sebesar 0,01\% dan bukan menunjukkan pengaruh yang signifikan.

Selain itu perbedaan temporer yang tidak berpengaruh terhadap persistensi laba disebabkan karena variasi data jumlah perbedaan temporer antar perusahaan sampel yang sangat signifikan, sehingga data yang diperoleh tidak berkelompok dan cenderung tidak berpengaruh. Selain itu perbedaan yang tidak sebanding dengan laba yang dihasilkan memungkinkan bahwa perbedaan temporer tidak memiliki pengaruh yang signifikan karna jumlahnya yang tidak terlalu besar yang disebabkan karena perusahaan sampel memiliki kebebasan untuk menggunakan prosedur akuntansinya, karena pada metode akuntansi terdapat kebijakan akrual dalam pengakuan trasaksinya, namun fiskal hanya mengakui cash basis dalam pelaporannya terhadap peristiwa yang benar- benar telah terjadi dan tidak bersifat pencadangan atau penyisihan. Selain itu terdapat metoda penyusutan yang beragam, namun fiskal hanya mengakui beberapa saja.

Perbedaan temporer kena pajak merupakan penyebab timbulnya beban pajak tangguhan atau pendapatan pajak tangguhan yang menimbulkan kewajiban atau aset pajak tangguhan. Perbedaan temporer dengan koreksi positif, jumlah yang dikoreksi akan menambah perhitungan beban pajak kini . Hal itu menyebabkan jumlah perbedaan temporer yang tadinya dapat menambah pajak penghasilan melalui pajak kini selanjutnya akan dihapus melalui pengurangan pajak penghasilan dalam bentuk penghasilan pajak tangguhan dan begitupun sebaliknya (Fitri, 2014).

Pengaruh aliran kas operasi terhadap persistensi laba. Berdasarkan hasil pengujian secara parsial dihasilkan variabel aliran kas operasi memiliki nilai thitung sebesar 3.666520 dan $t_{\text {tabel }}$ sebesar 1.9939 sehingga thitung $>t_{\text {tabel }}$ dan hasil uji signifikansi yang dilakukan menunjukkan tingkat signifikansi sebesar 0.0005 yang lebih kecil dari 0,05 dan $\mathrm{H}_{04}$ ditolak dan $\mathrm{H}_{\mathrm{A} 4}$ diterima yang artinya hasil pengujian menunjukkan variabel aliran kas operasi memiliki pengaruh terhadap persistensi laba secara parsial. Selain itu koefisien regresi pada variabel aliran kas operasi bernilai positif yang menunjukkan bahwa setiap peningkatan satu satuan aliran kas operasi maka persistensi laba akan mengalami peningkatan sebesar 0.259615. Hasil tersebut sejalan dengan hipotesis yang dibangun oleh penulis, dimana aliran kas operasi berpengaruh positif terhadap persistensi laba.

Hal ini disebabkan karena selama tahun penelitian perusahaan sampel lebih banyak mendapatkan kas dibandingkan mengeluarkannya, dengan kata lain perusahaan memiliki kas untuk melakukan opersionalnya kembali tanpa harus meminjam atau mencari modal kepada pihak lain. Apabila operasional perusahaan baik maka akan menghasilkan laba yang baik pula. Pada hasil deskriptif variabel aliran kas operasi terdapat 34 observasi yang memiliki aliran kas operasi diatas rata-rata dan sisanya 41 observasi berada di bawah ratarata dengan rasio nilai rata-rata 0,131 yang memiliki arti sebagian besar perusahaan sampel memperoleh kas dan dapat melakukan operasional perusahaan dengan baik untuk menghasilkan laba terutama dalam mempertahankan dan meningkatkan laba. 
Hasil ini sesuai dengan penelitian sebelumnya yang telah dilakukan oleh Dewi (2015) yang menyatakan bahwa arus kas operasi berpengaruh positif terhadap persistensi laba. Namun, hasil ini berlawanan dengan Chowijaya (2014) yang menyatakan bahwa aliran kas operasi tidak berpengaruh terhadap persistensi laba.

\section{PENUTUP}

Simpulan. Tujuan dilakukannya penelitian ini adalah untuk mengetahui seberapa besar pengaruh book tax differences dan aliran kas operasi terhadap persistensi laba. Berdasarkan analisis regresi data panel, menunjukan bahwa perbedaan permanen, perbedaan temporer dan aliran kas operasisecara simultan berpengaruh signifikan terhadap persistensi laba. Secara parsial hanya aliran kas operasi yang berpengaruh signifikan dengan arah positif terhadap persistensi laba sedangkanperbedaan permanen dan perbedaan temporer tidak berpengaruh terhadap persistensi laba.

Saran. Saran untuk penelitian selanjutnya adalah menambah variabel-variabel lain seperti rasio keuangan, tingkat hutang, pertumbuhan penjualan dan biaya pajak terhutang. Karena variabel dalam penelitian ini hanya mewakili 13,7\% dalam menjelaskan persistensi laba. Selain itu jumlah tahun penelitian yang lebih banyak dan objek dari berbagai sektor dapat menambah referensi bagi perusahaan dalam melihat persistensi laba.

Persistensi laba dapat menjadi pertimbangan bagi para investor dalam menginvestasikan dananya. Selain itu terdapat jumlah aliran kas operasi yang dapat menjadi pertimbangan apakah perusahaan menggunakan dananya untuk kegiatan operasional atau kegiatan lain yang bersifat non operasional.

Bagi perusahaan, sebaiknya memperhatikan kebijakan-kebijakan fiskal yang ditetapkan dalam membuat tax planning, khususnya dalam mempengaruhi besar kecilnya laba setelah pajak. Terutama pada item perbedaan temporer yang dapat dijadikan pajak tangguhan yang menimbulkan efek dikemudian hari dan dapat menyebabkan laba rendah atau tidak persisten. Perusahaan juga harus memperhatikan tingkat persisten yang dihasilkan oleh laba sebagai pengukur kinerja dan menjadi motivasi perusahaan untuk terus meningkatkan laba.

\section{DAFTAR RUJUKAN}

Amelia, Wira., Zirman., dan Diyanto, Volta. (2013) "Pengaruh Book tax differences, aliran kas dan tingkat hutang terhadap perubahan laba”. Jurnal Online Mahasiswa Fakultas Ekonomi Universitas Riau, Vol 1 No 2 Oktober 2014 ISSN 2355-6854.

Ariefianto, M. D. (2012) Ekonometrika. Jakarta: Penerbit Elangga.

Chowijaya, Andriansyah. (2014) Pengaruh Laba Akuntansi, Laba Fiskal, dan Arus Kas Operasi terhadap Persistensi Laba. STIE Multi Data Palembang.

Dewi, Ni Putu Lestari dan Putri. (2015) "Pengaruh Book-Tax Differences, Arus Kas Operasi, Arus Kas Akrual dan Ukuran Perusahaan pada Persistensi Laba”. E-jurnal Akuntansi Universitas Udayana, 10.1 (2015) : 244-260 , ISSN :2302-8556.

Fajri, Achmad., dan Mayangsari, Sekar. (2012) "Pengaruh Perbedaan Laba Akuntansi dan Laba Pajak terhadap Manajemen Laba dan Persistensi Laba”. Media Riset Akuntansi, Auditing\& Informasi, Volume 12, Nomor.1, April 2012. ISSN: 2442-9708. 
Gunadi. (2009) Akuntansi Pajak Sesuai dengan Undang- Undang Pajak Baru. Jakarta: Grasindo.

Hanlon, M. (2005) "The persistence and pricing of earnings, accruals and cash flows when firms have large book-tax differences”. The Accounting Review 80 (1):137-166.

Ikatan Akuntan Indonesia. (2015) Standar Akuntansi Keuangan. Jakarta: Salemba.

Penman, S. 2001. Financial Statement Analysis and Security Valuation. New York: McGrawHill Irwan.

Penman, Stephen.H \& Zhang, X.J. (1999) Accounting Conservatism, the Quality of Earnings,and stock returns. University of California, Berkeley.

Persada, Aulia Eka dan Martani, Dwi. (2010) “Analisis Faktor yang Mempengaruhi Book Tax Gap dan pengaruhnya terhadap Persistensi Laba”. Jurnal Akuntansi dan Keuangan Indonesia. Volume 7- No.2. Desember 2010. ISSN: 2406-9701.

Pertiwi, Intan Ratna dan Zulaikha. (2014) “Analisis Pengaruh Book-Tax Differencespada Persistensi Laba”. Diponegoro journal of accounting Volume 3, Nomor 3 Tahun 2014. ISSN: 2337-3806.

Poernomo, Yosep. (2008) Modul Akuntansi Perpajakan. Modul Tidak Dipublikasikan, Badan Pelatihan dan Pendidikan Keuangan.

Resmi, Siti. (2014) Perpajakan Teori dan Kasus. Jakarta: Salemba Empat.

Reeve, J.,Warren, C., Duchac,J.,Wahyuni, E., Soepriyanto,G., Jusuf,A., \& Djakman,C. (2009) Pengantar Akuntansi. Jakarta: Salemba Empat.

Revsine, Collins, dan Johnson.(2005) Financial Reporting and Analysis. New Jersey: Prentice Hall.

Scott, William R. (2000) Financial Accounting Theory. Prentice Hall Inc. Ontario.

Saputro, N. A. (2011) "Pengaruh Book-Tax Differences Terhadap Pertumbuhan Laba (Studi Empiris Pada Perusahaan Manufaktur Yang Terdaftar Di Bursa Efek Indonesia Tahun 2008 - 2010)”. Semarang : BP UNDIP.

Sloan, R. G. (1996) Do Stock Prices Fully Reflect Information in Accruals and Cash flows about future earnings?. The Accounting Review, Vol. 71, No. 3. (Jul., 1996), pp. 289315.

Suandy, Erly. (2001) Perencanaan Pajak. Jakarta: Salemba Empat.

Subramanyam, K.R\& Wild,John. (2010) Analisis laporan keuangan. Jakarta: Salemba Empat.

Sutopo, Bambang. (2007) Manajemen Laba dan Manfaat Kualitas Laba dalam Keputusan Investasi, Universitas Sebelas Maret, Surakarta.

Suwardjono. (2010) Teori Akuntansi. Yogyakarta: BPFE.

Triyono. (2007) "Analisis Karakteristik Fundamental Perusahaan sebagai Penentu Kualitas Laba”. Journal Benefit.

Wijayanti, Handayani. (2006) “Analisis Pengaruh Perbedaan Laba Akuntansi dan Laba Fiskal terhadap Persistensi Laba, Akrual dan Arus Kas”. Simposium NasionalAkuntansi 9. 